\title{
ANALISIS FAKTOR-FAKTOR PENENTU RESIKO KERAWANAN PANGAN KABUPATEN BARITO KUALA
}

\author{
Ahmad Yunani, Rusdiansyah, Siti Mutmainah Zulfaridatul Yaqin, Khairi Fahlevi, Ali \\ Wardhana \\ (Program Studi Ekonomi Pembangunan Fakultas Ekonomi dan Bisnis Universitas \\ Lambung Mangkurat, (yunaniunlam@gmail.com)
}

\begin{abstract}
This research is to know the indicator and mapping of risk area of food insecurity in Barito Kuala Regency. Map the condition of food resistance / vulnerability in Barito Kuala. Identify and analyze issues and issues related to potential risks of food insecurity in Barito Kuala. Data and information collected (secondary data and primary data) then update data, compile, tabulate data and process spatial data (mapping). The methods used in vulnerability identification and food insecurity above use the MINITAB analysis tool as a statistical analysis tool that can compile as well as several variables for composite analysis. Then for the distribution of vulnerability and food security using Arcgis, a mapping tool that has been widely used in spatial analysis. Through principal component analysis (Principal Component Analysis / PCA) has defined components that affect the preparation of food insecurity in Barito Kuala through 7 (seven) indicators are generated components that affect the following: The main component / PC 1 Number shop / grocery shop, health facilities, main components / PC 2 access roads, the percentage of poverty, main components / PC 3 Malnutrition, access jalanm, main components / PC 4 health facilities, infant mortality and maternal, main components / PC 5 percentage of poverty, access roads, the main component / PC 6 Healthcare facilities, infant mortality and maternal melahirkan. Hasil this study concludes that there are 12 villages that entered the category of potentially insecure priority 1, priority 2 alert entered the category of food insecurity as much as 26 villages, for the three priority categories of food insecurity there were 65 alert Village and enter the category of priority 4, priority 5, priority 6 in safe condition of food insecurity total as much as 97 village. The strategy for improving food security needs to be done through the dual track approach (twin track approaches), namely: a short-term approach by seeking to build economic development of rural communities based on agriculture in an effort to increase the added value and employment opportunities. The medium and long term approach is to meet the adequacy of food and nutrition of the poor and food insecure groups with an empowerment approach involving participation and the role of activities of all components.
\end{abstract}

\section{Keywords: Food Insecurity, economic development}

Abstrak : Penelitian ini untuk mengetahui indikator dan pemetaan daerah resiko kerawanan pangan di Kabupaten Barito Kuala. Memetakan kondisi ketahanan/kerawanan pangan di Barito Kuala. Mengidentifikasi dan menganalisis isu dan permasalahan terkait kemungkinan potensi resiko kerawanan pangan di Barito Kuala. Data dan informasi yang telah dikumpulkan (data sekunder dan data primer) kemudian dilakukan pemutakhiran data, kompilasi, tabulasi data dan mengolah data spasial (pemetaan). Metode yang digunakan dalam identifikasi kerentanan dan kerawanan pangan di atas menggunakan alat analisis MINITAB sebagai alat analisis statistika yang dapat mengkompilasi sekaligus beberapa variabel untuk analisis komposit. Kemudian untuk sebaran kerawanan dan ketahanan pangan menggunakan Arcgis, suatu alat pemetaan yang sudah banyak digunakan dalam 
analisis spasial. Melalui analisa komponen utama (Principal Component Analysis/PCA) telah ditentukan komponen yang mempengaruhi dalam penyusunan kerawanan pangan di Barito Kuala melalui 7 (tujuh) indikator tersebut dihasilkan komponen-komponen yang mempengaruhi sebagai berikut :Komponen utama / PC 1 Jumlah Warung/toko kelontongan, fasilitas kesehatan, Komponen utama / PC 2 Akses jalan, persentase kemiskinan, Komponen utama / PC 3 Gizi buruk, akses jalanm, Komponen utama / PC 4 Fasilitas kesehatan, Kematian balita dan ibu melahirkan, Komponen utama / PC 5 Persentase kemiskinan, akses jalan, Komponen utama / PC 6 Fasilitas Kesehatan, kematian balita dan ibu melahirkan.Hasil penelitian ini menyimpulkan ada 12 desa yang masuk katagori prioritas 1 berpotensi rawan pangan, masuk katagori prioritas 2 waspada rawan pangan sebanyak 26 desa, untuk katagori prioritas 3 awas rawan pangan terdapat 65 desa dan masuk katagori prioritas 4, prioritas 5, prioritas 6 dalam kondisi aman rawan pangan totalnya sebanyak 97 desa. Strategi peningkatan ketahanan pangan perlu dilakukan melalui pendekatan jalur ganda (twin track approaches) yaitu : Pendekatan jangka pendek dengan mengupayakan membangun peningkatan perekonomian masyarakat pedesaan yang berbasis pertanian pada upaya peningkatan nilai tambah dan peluang penyediaan lapangan kerja. Pendekatan jangka menengah dan panjang adalah dengan memenuhi kecukupan pangan dan gizi golongan masyarakat miskin dan rawan pangan dengan pendekatan pemberdayaan melibatkan partisipasi dan peran akitf seluruh komponen.

\section{Kata Kunci : Kerawanan Pangan, Pembangunan Ekonomi}

\section{Pendahuluan}

Kebutuhan pangan merupakan suatu kebutuhan pokok yang wajib bagi seluruh bangsa di dunia untuk memperhatikan dan menjadi prioritas dalam suatu perencanaan pembangunan. Meningkatnya pertumbuhan penduduk dan semakin berkurangnya lahan pertanian sudah menjadi isu nasional dan isu internasional terhadap ketersediaan pangan. Kemampuan lahan pertanian yang dalam memenuhi kebutuhan hajat hidup masyarakat tidak sama bagi tiap negara atau tiap kawasan. Ada negara atau wilayah yang mampu menyuplai kebutuhan pokok masyarakatnya namun banyak negara perlu memerlukan ketersediaan yang harus disuplai dari luar negara maupun luar wilayahnya. Masalah ketersediaan pangan ini sangat berkaitan dengan derajat kesehatan masyarakat.

Permasalahan yang sama ini juga sudah dirasakan di Indonesia pada daerah-daerah yang kawasan pertanian begitu sempit atau daerah yang kurang subur untuk pertanian sangat begitu dirasakan oleh masyarakatnya misalnya daerah Nusa Tenggara Timur hal ini begitu berdampak terutama dimusim kemarau. Perlu daerah lain diluar kepulauan Timor untuk membantu mensuplai kebutuhan pokok.
Kondisi yang berbeda seperti di Kalimantan Selatan khususnya Kabupaten Barito Kuala yang memiliki sumberdaya pertanian yang cukup besar dengan luasan pertanian padi hampir 100.000 Ha. Diketahui bahwa Kabupaten Barito Kuala satu diantara 13 kabupaten/kota yang di Kalimantan Selatan dengan letak Secara geografis kedudukannya terletak di $2^{\circ} 29^{\prime} 50^{\prime \prime}-3^{\circ} 30^{\prime} 18^{\prime \prime}$ Lintang Selatan \&114²0'50"-11450'18" Bujur Timur. Kabupaten Barito Kuala merupakan salah satu kabupaten dari 13 kabupaten/kota di Provinsi Kalimantan Selatan yang berada paling barat dan berbatasan langsung dengan Provinsi Kalimantan Tengah.

Melihat potensi sumberdaya alam yang ada yang merupakan potensial pertanian maka sudah seharusnya pertanian merupakan andalan Kabupaten Barito Kuala yang diharapkan mampu menyediakan kebutuhan pangan bagi masyarakatnya. Namun dalam permasalahan pangan tidaknya hanya dapat diatasi dengan ketersediaannya saja melainkan juga pemenuhan gizi masyarakat yang berimbas pada derajat kesehatannya.

Penyebab utama dari rendahnya derajat kesehatan masyarakat miskin selain ketidakcukupan pangan adalah keterbatasan 
akses terhadap layanan kesehatan dasar, rendahnya mutu layanan kesehatan dasar, kurangnya pemahaman terhadap perilaku hidup sehat, dan kurangnya layanan kesehatan reproduksi. Rendahnya kecukupan pangan dan terbatasnya layanan kesehatan untuk masyarakat miskin dapat dilihat dari kasus kematian yang diakibatkan oleh gizi buruk. Pada tahun 2005, jumlah anak usia 0-4 tahun di Indonesia mencapai 20,87 juta. Hal ini berarti ada sekitar 1,67 juta anak balita yang menderita gizi buruk. Hal tersebut membuktikan bahwa akses masyarakat miskin memang masih terbatas terhadap layanan kesehatan yang memadai dan masih terjadinya keterlambatan pemberian layanan kesehatan.

Melihat permasalahan pangan diatas maka untuk skala yang lebih kecil yaitu kabupaten/kota khususnya Kabupaten Barito Kuala maka perlu menjadi perhatian serius dalam menyikapi wilayah-wilayah yang ada kecenderungan terjadi kerawanan pangan, walaupun selama ini Kabupaten Barito Kuala merupakan salah satu penyangga pangan di Kalimantan Selatan, Perlu suatu langkah awal untuk melakukan kajian apakah kerentanan pangan sampai kerawanan pangan ada terjadi di Barito Kuala? Jika hal tersebut ada terjadi pada wilayah atau daerah mana saja yang sudah terjadi? Untuk selanjutnya langkah apa yang diambil untuk mengatasi permasalahan tersebut?. Rumusan Masalah Penelitian ini adalah bagaimana indikator dan pemetaan daerah resiko kerawanan pangan di Kab. Barito Kuala.Tujuan Penelitian ini adalah memetakan kondisi ketahanan/kerawanan pangan di Barito Kuala dan mengidentifikasi dan menganalisis isu dan permasalahan terkait kemungkinan potensi resiko kerawanan pangan di Barito Kuala.

Konsep Malthus yang menyatakan bahwa pertumbuhan pangan bagaikan deret hitung dan pertumbuhan penduduk bagai deret ukur, nampaknya mendapat momentumnya sekarang. Bangsa Indonesia denganpertumbuhan penduduk positif, apabila tidak disertai dengan kenaikan produksi pangan, maka akan berpeluang menghadapi persoalan pemenuhan kebutuhan pangan penduduknya di masa datang. Kebutuhan pangan senantiasameningkat seiring dengan peningkatan jumlah penduduk. Di sisi pemenuhannya,tidak semua kebutuhan pangan dapat dipenuhi, karena kapasitas produksi dan distribusi pangan semakin terbatas. Hal ini menyebabkan ketidakstabilan pangan antara kebutuhan dan pemenuhannya secara nasional.Dengan demikian pemenuhan kebutuhan pangan ini menjadi sangat penting dan strategis dalam rangka mempertahankan kedaulatan negara, melalui tidak tergantung pada

impor pangan dari negara maju. Ketergantungan suatu negara akan impor pangan (apalagi dari negara maju), akan mengakibat kan pengambilan keputusan atas segala aspek kehidupan menjadi tidak bebas atau tidak merdeka, dan karenanya negara menjadi tidak berdaulat secara penuh (Arifin, 2004).

Kebutuhan pangan merupakan suatu kebutuhan pokok yang wajib bagi seluruh bangsa di dunia untuk memperhatikan dan menjadi prioritas dalam suatu perencanaan pembangunan. Meningkatnya pertumbuhan penduduk dan semakin berkurangnya lahan pertanian sudah menjadi isu nasional dan isu internasional terhadap ketersediaan pangan. Kemampuan lahan pertanian yang dalam memenuhi kebutuhan hajat hidup masyarakat tidak sama bagi tiap negara atau tiap kawasan. Ada negara atau wilayah yang mampu menyuplai kebutuhan pokok masyarakatnya namun banyak negara perlu memerlukan ketersediaan yang harus disuplai dari luar negara maupun luar wilayahnnya. Masalah ketersediaan pangan ini sangat berkaitan dengan derajat kesehatan masyarakat.

Secara teoritis penjelasan mengenai Ketahanan Pangan dijelaskan yaitu suatukondisi terpenuhinya pangan bagi negara sampai dengan perseorangan, yang tercermin dari tersedianya pangan yang cukup, baik jumlah maupun mutunya, aman, beragam, bergizi, merata, dan terjangkau serta tidak bertentangan dengan agama, keyakinan dan 
budaya masyarakat, untuk dapat hidup sehat, aktif dan produktif secara berkelanjutan. (UU No. 18tahun2012tentangPangan).

Sebagaimana FIA 2005, FSVA Nasional 2009, FSVA Provinsi 2010 dan 2011, FSVA Kabupaten 2012 disusun berdasarkan tiga pilar ketahanan pangan: (i) ketersediaan pangan; (ii) akses terhadap pangan; dan (iii) pemanfaatan pangan.Ketersediaan pangan adalah ketersediaan pangan secara fisik di suatu wilayah dari segala sumber, baik itu produksi pangan domestik (netto), perdagangan pangan dan bantuan pangan. Ketersediaan pangan ditentukan oleh produksi pangan di wilayah tersebut, perdagangan pangan melalui mekanisme pasar di wilayah tersebut, stok yang dimiliki oleh pedagang dan cadangan pemerintah \&bantuan pangan dari pemerintah/organisasi lainnya.

Pangan meliputi produk serealia, kacang-kacangan, minyak nabati, sayursayuran, buahbuahan, rempah, gula, dan produk hewani. Karena porsi utama dari kebutuhan kalori harian berasal dari sumber pangan karbohidrat, yaitu sekitar separuh dari kebutuhan energi per orang per hari, maka yang digunakan dalam analisa kecukupan pangan yaitu karbohidrat yang bersumber dari produksi pangan pokok serealia, yaitu padi, jagung, dan umbi-umbian (ubi kayu dan ubi jalar) yang digunakan untuk memenuhi tingkat kecukupan pangan pada tingkat provinsi maupun kabupaten.

Dalam penyelenggaran ketahanan pangan, peran Pemerintahan Provinsi dan Kabupaten/Kota dalam mewujudkan ketahanan pangan sebagaimana diamanatkan dalam Pasal 13 Peraturan Pemerintah Nomor 68 Tahun 2002 adalah melaksanakan dan bertanggung jawab terhadap penyelenggaraan ketahanan pangan di wilayah masing-masing dan mendorong keikutsertaan masyarakat dalam penyelenggaraan ketahanan pangan, dilakukan dengan: (a) Memberikan informasi dan pendidikan ketahanan pangan (b) Meningkatkan motivasi masyarakat (c) Membantu kelancaran penyelenggaraan ketahanan pangan (d)
Meningkatkan kemandirian ketahanan pangan.

Komoditi pangan strategis meliputi beras, jagung, cabai merah, gula pasir, bawang merah, daging ayam, daging sapi, telur ayam, dan minyak goreng. Kesembilan komoditi ini sering disebut dengan bahan pangan strategis di Indonesia melihat pola konsumsi Indonesia yang lazim menggunakan bahan pangan ini yang sudah menjadi budaya di masyarakatnya. Dalam PPRI No. 68 Tahun 2002, untuk memenuhi penyediaan dalam rangka pemenuhan kebutuhan konsumsi rumah tangga yang terus berkembang dilakukan dengan: mengembangkan sistem produksi pangan yang bertumpu pada sumberdaya, kelembagaan dan budaya lokal; mengembangkan efisiensi sistem usaha pangan; mengembangkan teknologi produksi pangan; mengembangkan sarana dan prasarana produksi pangan.

Akses Pangan adalah kemampuan rumah tangga untuk memperoleh cukup pangan, baik yang berasal dari produksi sendiri, stok, pembelian, barter, hadiah, pinjaman dan bantuan pangan. Ketersediaan pangan di suatu daerah mungkin mencukupi, akan tetapi tidak semua rumah tangga memiliki akses yang memadai baik secara kuantitas maupun keragaman pangan melalui mekanisme tersebut di atas. Akses pangan tergantung pada daya beli rumah tangga yang ditentukan oleh penghidupan rumah tangga tersebut. Penghidupan terdiri dari kemampuan rumah tangga, modal/aset (sumber daya alam, fisik, sumber daya manusia, ekonomi dan sosial) dan kegiatan yang dilakukan untuk memenuhi kebutuhan hidup dasar penghasilan, pangan, tempat tinggal, kesehatan dan pendidikan.

Rumah tangga yang tidakmemiliki sumber penghidupan yang memadai dan berkesinambungan, sewaktu-waktu dapat berubah, menjadi tidak berkecukupan, tidak stabil dan daya beli menjadi sangat terbatas, yang menyebabkan tetap miskin dan rentan terhadap kerawanan pangan. Aspek Akses terhadap pangan, meliputi indikator-indikator sebagai berikut:Persentase penduduk hidup di 
bawah garis kemiskinan. Jalan utama desa/kelurahan dapat dilalui kendaraan bermotor roda 4 atau lebih.Persentase rumah tangga tanpa akses listrik.

Dimensi ke-tiga dari ketahanan pangan adalah pemanfaatan pangan. Pemanfaatan pangan meliputi: a) Pemanfaatan pangan yang bisa di akses oleh rumah tangga, dan b) kemampuan individu untuk menyerap zat gizi pemanfaatan makanan secara efisien oleh tubuh.Aspek pemanfaatan pangan meliputi Indikator-indikator sebagai berikut:Jumlah kematian balita dan ibu saat melahirkan, Jumlah penderita gizi buruk, daan Jumlah sarana/fasilitas kesehatan

Pengembangan ketahanan pangan mempunyai perspektif pembangunan yang sangat mendasar karena berpengaruh langsung terhadap keberhasilan pengembangan kualitas sumber daya manusia. Hal ini ditentukan oleh keberhasilan pemenuhan kecukupan dan konsumsi pangan dan gizi.

Konsumsi pangan menyangkut upaya peningkatan pengetahuan dan kemampuan masyarakat agar mempunyai pemahaman atas pangan, gizi dan kesehatan yang baik, sehingga dapat mengelola konsumsinya secara optimal. Konsumsi pangan hendaknya memperhatikan asupan pangan dan gizi yang cukup dan berimbang, sesuai dengan kebutuhan bagi pembentukan manusia yang sehat, kuat, cerdas dan produktif.

Dalam subsistem konsumsi terdapat aspek penting lain yaitu aspek diversifikasi. Diversifikasi pangan merupakan suatu cara untuk memperoleh keragaman konsumsi zat gizi sekaligus mengurangi ketergantungan masyarakat atas satu jenis pangan pokok tertentu, yaitu beras. Ketergantungan yang tinggi dapat memicu instabilitas apabila pasokan pangan tersebut terganggu. Sebaliknya agar masyarakat menyukai pangan alternatif perlu peningkatan cita rasa, penampilan dan kepraktisan pengolahan pangan agar dapat bersaing dengan produk-produk yang telah ada. Dalam kaitan ini peranan teknologi pengolahan pangan sangat penting. (Yunastiti, 2008).

\section{Metode}

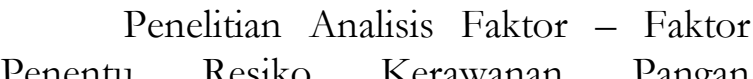
Kabupaten Barito Kuala terdiri atas beberapa sub pekerjaan yang bersinergi sehingga dalam rancangan pelaksanaanya memerlukan pendekatan yang menyeluruh dan terintegrasi antara satu dengan lainnya. Data sekunder diperoleh dari data-data otentik yang terkait langsung dengan pekerjaan penyusunan dokumen ini. Data-data tersebut berasal dari dokumen-dokumen Norma, Standar, Pedoman dan Kriteria (NSPK) baik yang berlaku secara nasional maupun yang dikeluarkan oleh Pemerintah Kabupaten Barito Kuala.

Data-data sekunder yang diperlukan diantaranya: Data-data Pangan (pertanian pangan, peternakan, perikanan), Data profil wilayah Kabupaten Barito Kuala. Data dasar kependudukan, sosial dan ekonomi masyarakat Kabupaten Barito Kuala.Dokumen perencanaan pembangunan daerah yang memuat kebijakan, tujuan dan sasaran pembangunan daerah, meliputi Rencana Pembangunan Jangka Menengah Daerah (RPJMD) Kabupaten Barito Kuala;Dokumen kebijakan spasial yaitu Rencana Tata Ruang Wilayah (RTRW) Kabupaten Barito Kuala.Data-data kesehatan masyarakat. Datadata energi listrik, Data-data infrastruktur jalan, Data-data lainnya yang relevan.

Data dan informasi yang telah dikumpulkan (data sekunder dan data primer) kemudian dilakukan pemutakhiran data, kompilasi, tabulasi data dan mengolah data spasial (pemetaan). Metode yang digunakan dalam identifikasi kerentanan dan kerawanan pangan di atas menggunakan alat analisis MINITAB sebagai alat analisis statistika yang dapat mengkompilasi sekaligus beberapa variabel untuk analisis komposit. Kemudian untuk sebaran kerawanan dan ketahanan pangan menggunakan Arcgis, suatu alat pemetaan yang sudah banyak digunakan dalam analisis spasial. 
Dari analisis data kemudian haslinya disajikan dalam sebuah konstruksi pembahasan secara sistematis berupa hasil pembahasan,

\section{Hasil dan Pembahasan}

\section{Analisa Individual}

Berdasarkan data-data yang sudah dikumpulkan maka dilakukan analisa melalui analisa Individual.

\section{Jumlah Warung/Toko Kelontong}

Salah satu indikator yang digunakan pada pemenuhan akses pangan di desa-desa adalah ketersediaan warung/toko kelontong sebagai penyedia bahan pangan. Indikator ini masuk dalam pengukuran kerawanan pangan karena merupakan gambaran kemudaan dalam pemenuhan bahan pangan walaupun indikator ini masih belum menunjukkan secara riil kemampuan masyarakat dalam memenuhi perhitungan, tabel, grafik, maupun diagram yang kemudian diinterpretasikan sesuai dengan tujuan dan sasaran.

kebutuhan pangan di desa-desa. Karena secara umum wilayah Barito Kuala secara garis besarnya merupakan wilayah pertanian padi, namun indikator ini merupakan indikator yang sudah ditetapkan oleh Badan Ketahanan Pangan Pusat. Banyaknya jumlah warung/toko kelontongan merupakan gambaran aktivitas ekonomi desa karena melalui toko/warung inilah perputaran ekonomi masyarakat desa dapat digambarkan.Hasil analisa pada data jumlah warung/toko kelontongan di desa-desa diperoleh hasil sebagai berikut:

\section{Tabel 1}

Hasil analisa Indikator Individual Jumlah Warung/Toko Kelontongan

\begin{tabular}{|c|c|c|c|}
\hline Prioritas & Range Warung & Jumlah Desa & $\%$ Desa \\
\hline Prioritas 1 & $<15$ & 100 & 50 \\
\hline Prioritas 2 & $15 \mathrm{~s} / \mathrm{d} 37$ & 83 & 41,5 \\
\hline Prioritas 3 & $>37$ & 17 & 8,5 \\
\hline \multicolumn{2}{|c|}{ Total } & 200 & 100 \\
\hline
\end{tabular}

Sumber : Analisis, 2016

Keterangan :

Prioritas 1 warna merah menunjukkan Kerentanan

Prioritas 2 warna kuning menunjuk.kan waspada

Prioritas 3 warna hijau menunjuk.kan aman

Melihat hasil analisa diatas menunjukkan bahwa ada seratus desa yang masuk katagori rentan akses pangan karena jumlah toko/warung kelontongannya di bawah 15 buah ditiap desa. Pada perlu diketahui bahwa luas desa di wilayah Barito Kuala cenderung Persentase Penduduk di Bawah Garis Kemiskinan luas hal ini menggambarkan tiap masyarakat yang ingin memperoleh kebutuhan pangannya memerlukan jarak dan waktu tempuh yang lebih jauh dan sedikit lama. 
Analisis pada data jumlah penduduk miskin di Barito Kuala menghasilkan prioritasprioritas terhadap kerawanan pangan berdasarkan jumlah penduduk miskin yang dikeluarkan oleh Dinas Sosial, Tenaga Kerja dan Transmigrasi Kabupaten Barito Kuala. Data yang mereka keluarkan sudah berdasarkan nama dan alamat tempat tinggalnya. Kemiskinan merupakan data penting dalam indikator kerawanan pangan karena dari satu data ini sudah dapat menggambarkan kondisi riil masyarakatnya di desa. Dari data ini menggambarkan tingkat kemampuan masyarakat terhadap pemenuhan kebutuhan pangan dan gizi mereka.

Dilihat dari tingkat kemiskinan di desa maka desa-desa yang masuk dalam katagori rawan pangan akibat kemiskinan sebanyak 47 desa atau 23,5\% dari total desa/kelurahan yang ada di Kabupaten Barito Kuala dengan total jumlah penduduk miskin di Kabupaten Barito Kuala tahun 2015 sebanyak 75.866 jiwa. Kemiskinan yang ada adalah masuk dalam katagori kemiskinan obsolut. Rata-rata masyarakat yang masuk dalam katagori miskin ini tidak memiliki pekerjaan tetap dan sebagian besar merupakan buruh tani yang penghasilan pertahun hanya mengandalkan pekerjaan musiman tergantung dari musim tanam atau musim panen di Kabupaten Barito Kuala. Upah yang mereka peroleh sebagai buruh tani sangat minim hampir tidak bisa mencukupi kebutuhan minimal sehari-hari rumah tangga mereka sehingga selain buruh tani mereka juga mempunyai usaha sampingan beragam, diantaranya sebagai nelayan/pencari ikan, buruh bangunan, pencari kayu galam dan lainlain.

Tabel 2

Prioritas Persentase Kemiskinan Desa di Kabupaten Barito Kuala

\begin{tabular}{|c|c|c|c|}
\hline Prioritas & Range kemiskinan & Jumlah Desa & \% Desa \\
\hline Prioritas 3 & $<0,29$ & 70 & 35 \\
\hline Prioritas 2 & 0,29 s/d 0,65 & 83 & 41,5 \\
\hline Prioritas 1 & $>65$ & 47 & 23,5 \\
\hline \multirow{2}{*}{ Sumber: Analisis, 2016 } & Total & $\mathbf{2 0 0}$ & $\mathbf{1 0 0}$ \\
\cline { 2 - 4 }
\end{tabular}

Kecamatan Alalak merupakan kecamatan yang masuk katagori rawan pangan dengan tingkat kemiskinan terbanyak yang terdapat dalam 11 desa, diikuti oleh Tamban 9 desa dan Mekarsari 8 desa. Dilihat dari tiga kecamatan tersebut dketahui bahwa Kecamatan Alalak dan Kecamatan Tamban merupakan kecamatan cepat tumbuh khusus untuk Alalak pertumbuhan jumlah penduduk, perkembangan perumahan dan industri sangat berkembang pesat disana karena merupakan daerah penyangga Kota Banjarmasin.

Efek dari peningkatan perekonomian di kawasan ini berakibat pula pada peningkatan kemiskinan diwilayah ini yang disinyalir peningkatan kemiskinan ini efek dari masuknya penduduk dari luar Kabupaten Barito Kuala yang mencari peruntungan nasib di kota Banjarmasin namun berdomisili di sekitar Kecamatan Alalak.

Selain itu tutupnya industri perkayuan sejak tahun 2005 berdampak pada banyaknya pemutusan hubungan kerja disektor ini yang sebagian besar sudah berdomisili di wilayah kecamatan Tamban dan Kecamatan Alalak. Otomatis akan meningkatkan peningkatan kemiskinan di wilayah Barito Kuala. Transformasi struktural dari sektor industri kesektor pertanian memang terjadi namun 
masih belum mampu menampung seluruh pengangguran yang sudah terjadi.

\section{Akses Jalan}

Salah satu faktor penyebab terjadi kerawanan pangan adalah masalah akses jalan, dimana hampir sebagian besar para ahli ekonomi pembangunan dan masalah kemiskinan menyatakan dampak dari besarnya tingkat kemiskinan dan lambatnya pertumbuhan ekonomi karena masalah infrastruktur terutama jalan. Mengenai kondisi geografis dari Barito Kuala sudah dibahas pada pembahasan sebelumnya sehingga salah satu indikator utama kerawanan pangan adalah akses jalan yang dapat dilalui oleh kendaraan bermotor roda 4.sebagai prioritas penentu untuk kerawanan pangan.

Hasil analisa individual dari data indikator akses jalan diketahui hasil pada tabel di bawah ini. Dari total 200 desa/kelurahan di Barito Kuala hanya tersisa 15 Desa yang benarbenar tidak bisa dilalui kendaraan bermotor roda empat sepanjang waktu. Berkurangnya jumlah desa yang masuk katagori prioritas 1 (rawan pangan karena akses jalan) karena ada upaya pemerintah Kabupaten Barito Kuala meningkatkan infrastruktur jalan pada jalanjalan kabupaten.

Tabel 3

Prioritas Akses Jalan di Desa-Desa Kabupaten Barito Kuala

\begin{tabular}{|c|c|c|c|}
\hline Prioritas & Akses Jalan & Jumlah Desa & \% Desa \\
\hline Prioritas 3 & $<2$ & 142 & 71 \\
\hline Prioritas 2 & 2 s/d 3 & 43 & 21,5 \\
\hline Prioritas 1 & $>3$ & 15 & 7,5 \\
\hline & Total & $\mathbf{2 0 0}$ & $\mathbf{1 0 0}$ \\
\hline
\end{tabular}

Sumber: Hasil Analisis, 2016

Dari 15 desa di Barito Kuala yang belum bisa dilalui roda 4 sebagian besar berada di Kecamatan Tabunganen (dapat dilihat pada peta), desa-desa tersebut merupakan desa-desa yang sudah dari dulu akses jalannya masih belum terhubung. Upaya pembangunan infrastruktur dengan istilah Taman Sari Bunga (Tamban, Mekarsari, Tabunganen) dimasa kepemimpinan H. Hasanuddin Murad telah berhasil membuka akses sampai ke Kecamatan Tabunganen walau masih ada beberapa desa yang masih dalam upaya lanjutan untuk menghubungkan sampai ke desa-desa tersebut.

Dari seratus desa yang jumlah warung/toko kelontongan yang jumlahnya masih rendah, Kecamatan Tabunganen yang memiliki desa yang terbanyak yang katagori rentan akses pangan yaitu 11 desa diikuti Anjir Pasar 9 desa, Belawang dan Cerbon masingmasing 8 desa.
Melihat kondisi tersebut Kecamatan Tabunganen yang memiliki kondisi wilayah yang cukup luas dengan masih banyak akses jalan yang belum terhubung wajar jika jumlah warung/toko masih kurang, namun yang perlu menjadi perhatian Kecamatan Tabunganen merupakan produsen padi terbesar di Barito Kuala maka padi sebagai makanan pokok di masyarakat tidak akan sulit diperoleh di wilayah ini. Kerawanan pangan dilihat tidak hanya dari ketersediaan beras/padi saja namun pemenuhan kebutuhan gizi dalam hal ini protein hewan juga diperlukan.

\section{Rumah Tangga Tanpa Akses Listrik}

Akses listrik sebagai salah indikator penentuan rawan pangan merupakan standar yang dikeluarkan tim FSVA (Food Security and Volnerability Atlas) oleh Badan Ketahanan Pangan Kementerian Pertanian. Akses 
keluarga tanpa listrik dijadikan indikator karena listrik sebagai penyedia energi erat kaitannya dengan perkembangan wilayah dalam peningkatan ekonomi masyarakat dengan berkembangnya kegiatan-kegiatan home industry perorangan maupun oleh UMKM (usaha Mikro Kecil Menengah) yang dapat melibatkan masyarakat sekitar untuk aktif dan bekerja baik sebagai penghasilan utama maupun tambahan. Pendapatan yang diperoleh dapat digunakan untuk pemenuhan pangan dan gizi.mereka.
Data rumah tangga tanpa akses listrik diperoleh dari BPS Kabupaten Barito Kuala untuk selanjutnya diolah melalui analisa individual, rumah tangga tanpa akses listrik yang berada pada 30\% masuk katagori rawan terdapat sebanyak 44 desa (sekitar 22\%). Dilihat dari Indikator ini maka masih cukup banyak rumah tangga di desa-desa yang belum memperoleh akses listrik. Hal ini dikarenakan kondisi wilayah yang membuat sulitnya menyambungkan aliran listrik keseluruh desa yang aliran listriknya masih kurang.

\section{Tabel 4}

Prioritas Rumah Tangga Tanpa Akses Listrik

\begin{tabular}{|l|r|c|c|}
\hline Prioritas & Range Listrik & Jumlah Desa & \% Desa \\
\hline Prioritas 1 & $<1,05$ & 44 & 22 \\
\hline Prioritas 2 & 1,05 s/d 4,82 & 59 & 29,5 \\
\hline Prioritas 3 & $>4,82$ & 97 & 48,5 \\
\hline \multirow{2}{*}{} & Total & $\mathbf{2 0 0}$ & $\mathbf{1 0 0}$ \\
\cline { 2 - 4 }
\end{tabular}

Sumber:Hasil Analisis, 2016

\section{Jumlah Kematian Balita dan Ibu Melahirkan}

Jumlah desa dengan tingkat kematian balita dan ibu melahirkan dibawah 40 hari pasca melahirkan menjadi indikator penentu rawan pangan. Kondisi kematian pada saat-saat tersebut di atas dikarenakan ada kecenderungan akibat dari gizi buruk karena kurangnya asupan pangan.
Hasil analisa individual untuk indikator balita dan ibu melahirkan di Barito Kuala (sumber data Dinas Kesehatan Kab. Barito Kuala) hanya ada dua desa yang masuk katagori rawan yang terdapat di Desa Tinggiran II Kecamatan Tamban dan Desa Patih Selera Kecamatan Belawang, dengan tingkat kematian diatas dua orang. Kemudian yang masuk katagori Prioritas 2 atau awas sebanyak 52 desa atau $26 \%$ dan Sebanyak $73 \%$ masih aman.

\section{Tabel 5}

Prioritas Jumlah Desa atas Balita dan Ibu Melahirkan di Kabupaten Barito Kuala 


\begin{tabular}{|c|c|c|c|}
\hline Prioritas & $\begin{array}{l}\text { Range Kematian Balita dan } \\
\text { Ibu }\end{array}$ & Jumlah Desa & $\%$ Desa \\
\hline Prioritas 3 & $<1$ & 146 & 73 \\
\hline Prioritas 2 & $1 \mathrm{~s} / \mathrm{d} 2$ & 52 & 26 \\
\hline \multirow[t]{2}{*}{ Prioritas 1} & $>2$ & 2 & 1 \\
\hline & Total & 200 & 100 \\
\hline
\end{tabular}

Sumber: Analisis,2016

Pada grafik di bawah ini menggunakan data pada prioritas 2 masuk katagori awas terhadap kematian balita dan ibu dimana jumlah desa yang terbanyak masuk katagori awas ada pada kecamatan Alalak sebanyak 9 desa, disusul oleh Kecamatan Tamban dan Mekarsari masing-masing 6 desa.

Adanya angka kematian terhadap balita dan ibu melahirkan perlu diperhatikan dan diwaspada salah satu yang menjadi perhatian untuk penanganannya adalah masalah pemenuhan pangan karena banyak ditemukan kasus kematian balita dan ibu melahirkan akibat kurang pangan yang berdampak pada gizi buruk.

Peta rawan pangan berdasarkan indikator Kematian Balita dan Ibu Melahirkan di desa/kelurahan di Kabupaten Barito Kuala dapat dilihat pada gambar di bawah ini. Dimana pada peta nampak desa-desa yang masuk katagori rawan pangan karena indikator kematian Balita dan Ibu Melahirkan yang ditandai dengan warna merah sangat sedikit, namun yang masuk katagori awas yang ditandai kuning cukup banyak.

\section{Jumlah Penderita Gizi Buruk}

Gizi buruk merupakan indikator yang paling sering digunakan untuk mengukur masalah kesehatan dimasyarakat. Gizi buruk didifinisikan sebagai suatu kondisi manusia yang mengalami kondisi kesehatan rendah akibat kekurangan KEP (Kalori, energi dan Protein).

Gizi buruk terbagi atas dua katagori yaitu gizi buruk berdasarkan dibawah buku KMS (Kartu Menuju Sehat) ditandai dibawah garis merah (kondisi terendah kesehatan bayi dan balita, kemudian gizi buruk berdasarkan data klinis yaitu kondisi sesorang yang sedang menderita kesehatannya ditandai dengan kondisi lemah, tidak berdaya, kurus kering dan lain-lain akibat kekurangan Kalori, Energi dan Protein, untuk katagori ini tidak memandang usia penderita yang penting dinyatakan oleh hasil medis.

Hasil olah data mengenai penderita gizi buruk yang ada di desa-desa oleh Dinas Kesehatan Kabupaten Barito Kuala, setelah melalui analisa individual bahwa jumlah desa yang masuk dalam katagori rawan (prioritas 1) terdapat empat desa dengan jumlah penderita sebanyak 8 (delapan) orang yang berada pada desa Tabunganen Pemurus Kecamatan Tabunganen 2 penderita, Desa Purosari I Kecamatan Tamban 2 penderita, Desa Belandean Muara Kecamatan Alalak 2 penderita dan Desa Tamba Jaya Kecamatan Tabukan 2 penderita.

\section{Tabel 6}

Daftar Prioritas Jumlah Desa Dengan Penderita Gizi Buruk

Di Kabupaten Barito Kuala 


\begin{tabular}{|c|r|r|r|}
\hline Prioritas & Range gizi buruk & Jumlah Desa & \multicolumn{1}{|c|}{ \% Desa } \\
\hline Prioritas 3 & $<1$ & 174 & 87 \\
\hline Prioritas 2 & 1 & 22 & 11 \\
\hline Prioritas 1 & $>1$ & 4 & 2 \\
\hline & Total & $\mathbf{2 0 0}$ & $\mathbf{1 0 0}$ \\
\cline { 2 - 4 }
\end{tabular}

Sumber: Hasil Analisis, 2016

Kalau melihat data ini maka jumlah penderita gizi buruk di Kabupaten Barito Kuala masih kecil, walaupun masih katagori kecil namun harus tetap diantisipasi karena ada 22 Desa yang masuk katagori awas dengan jumlah penderita sebanyak 22 orang.

\section{Jumlah Sarana Fasilitas Kesehatan}

Fasilitas Kesehatan menurut Dinas Kesehatan Kabupaten Barito Kuala adalah fasilitas yang fungsinya sebagai unit layanan kesehatan murni tanpa ada fungsi campuran dengan kegiatan lain selain pelayanan kesehatan, pada saat ini sebagian besar pelayanan dasar kesehatan di desa diantaranya Puskesdes (Pusat Kesehatan Desa), Pustu (Puskesmas Pembantu), praktek dokter dan praktek bidan. Peran dari fasilitas kesehatan ini didesa-desa sangat penting sebagai layanan dasar/pertama kesehatan masyarakat. Banyaknya fasilitas kesehatan berdampak mengurangi resiko terjadinya gizi buruk dan resiko kematian akibat kasus penyakit dan kejadian lainnya.

Pada analisa data untuk jumlah sarana fasilitas kesehatan didesa-desa menggunakan data dari Dinas Kesehatan Kabupaten Barito Kuala. Data yang digunakan sudah berdasarkan petunjuk dari Kementerian Kesehatan terkait fasilitas kesehatan didesadesa. Menggunakan analisis individual didapat bahwa yang masuk katagori prioritas 1 sebanyak 163 desa atau 81,5\%. Pengukuran sudah mengikuti pedoman tim FSVA Kementerian Pertanian.

Tabel 7

Daftar Prioritas Rawan Pangan dari Indikator Fasilitas Kesehatan

\begin{tabular}{|l|c|r|r|}
\hline \multicolumn{1}{|c|}{ Prioritas } & Range Sarana Kesehatan & Jumlah Desa & \multicolumn{1}{c|}{ \% Desa } \\
\hline Prioritas 1 & $<2$ & 163 & 81,5 \\
\hline Prioritas 2 & 2 & 33 & 16,5 \\
\hline Prioritas 3 & $>2$ & 4 & 22 \\
\hline \multirow{2}{*}{} & Total & 200 & 120 \\
\cline { 2 - 5 }
\end{tabular}

Sumber: Hasil Analisis, 2016

Dari tabel di atas hanya 22 desa yang masuk katagori aman (Prioritas 3) desa yang memiliki fasilitas kesehatan cukup memadai. Minimnya fasilitas kesehatan masyarakat yang ada di desa-desa terkait dengan kemampuan Pemerintah Daerah dalam membangun fasilitas tersebut. Besarnya jumlah desa yang masuk katagori rawan karena fasilitas kesehatan ini menurut panduan tim FSVA karena satu fasilitas pelayanan dianggap belum mampu dalam memberikan pelayanan terhadap warga diperdesaan karena luasnya wilayah suatu desa. Kecamatan Alalak merupakan kecamatan dengan jumlah desa terbanyak yang kurang fasilitas kesehatannya ini sesuai dengan jumlah desa yang ada di kecamatan tersebut juga paling banyak memiliki desa ditiap kecamatannya.

\section{Analisa Komposit}

Tujuh data indikator dalam menganalisa kerawanan pangan setelah melalui tahapan 
Analisa Individual selanjutnya dianalisa dilakukan analisa Komposit. Dimana analisa Komposit merupakan Analisis situasi kerentanan terhadap kerawanan pangan suatu daerah disebabkan oleh kombinasi dari Menentukan Faktor Yang Berpengaruh Pada Kerawanan Pangan

Melalui analisa komponen utama (Principal Component Analysis/PCA) telah ditentukan komponen yang mempengaruhi dalam penyusunan kerawanan pangan di Barito

Komponen utama / PC $1=$ Jumlah Warung/toko kelontongan, fasilitas kesehatan

Komponen utama / PC $2=$ Akses jalan, persentase kemiskinan

Komponen utama / PC $3=$ Gizi buruk, akses jalan

Komponen utama / PC $4=$ Fasilitas kesehatan, Kematian balita dan ibu melahirkan

Komponen utama / PC $5=$ Persentase kemiskinan, akses jalan

Komponen utama / PC $6=$ Fasilitas Kesehatan, kematian balita dan ibu melahirkan

Selanjutnya dilakukan penentuan

indikator-indikator yang berpengaruh dengan

hasil sebagai berikut :

Tabel 8

Faktor-Faktor Penentu Resiko Kerawanan Pangan per Prioritas

\section{Faktor Penyebab}

Prioritas 1 (cluster 6)

1. Jumlah warung/toko

2. Fasilitas kesehatan

3. Akses jalan

4. Kemiskinan

Prioritas 3 (Cluster 5)

1. Jumlah Warung/toko

2. Fasilitas kesehatan

Prioritas 5 (cluster 4)

1. Kemiskinan

2. Akses jalan

Sumber: Hasil Analisis, 2016

Dalam peta yang dihasilkan ini bukan merupakan peta kondisi rawan pangan di desadesa, peta ini hanya menunjukkan akan adanya potensi desa/kelurahan yang berpotensi akan terjadi rawan pangan akibat faktor-faktor yang mempengaruhi tersebut diatas dengan analisa standar FSVA yang biasa digunakan. Hasil analisa dengan alat bantu program Minitab diperoleh desa-desa dengan masing-masing katagori dengan enam prioritas tersebut diatas

\section{Prioritas 2 (cluster 3)}

1. Akses jalan

2. Kemiskinan

3. Gizi buruk

\section{Prioritas 4 (Cluster 1)}

1. Fasilitas kesehatan

2. Kematian balita dan ibu melahirkan

\section{Prioritas 6 (cluster 2)}

1. Gizi buruk

2. Akses jalan

3. Kemiskinan

ada 12 desa yang masuk katagori prioritas 1 berpotensi rawan pangan, masuk katagori prioritas 2 waspada rawan pangan sebanyak 26 desa, untuk katagori prioritas 3 awas rawan pangan terdapat 65 desa dan masuk katagori prioritas 4, prioritas 5 , prioritas 6 dalam kondisi aman rawan pangan totalnya sebanyak 97 desa.

\section{Kesimpulan dan Rekomendasi}


Hasil analisa dengan alat bantu program Minitab diperoleh desa-desa dengan masing-masing katagori dengan enam prioritas tersebut diatas ada 12 desa yang masuk katagori prioritas 1 berpotensi rawan pangan, masuk katagori prioritas 2 waspada rawan pangan sebanyak 26 desa, untuk katagori prioritas 3 awas rawan pangan terdapat 65 desa dan masuk katagori prioritas 4, prioritas 5, prioritas 6 dalam kondisi aman rawan pangan totalnya sebanyak 97 desa.

Kerangka kerja yang sifatnya menyeluruh tentang penyebab dan jenis intervensi untuk meningkatkan ketahanan pangan digambarkan pada gambar berikut.

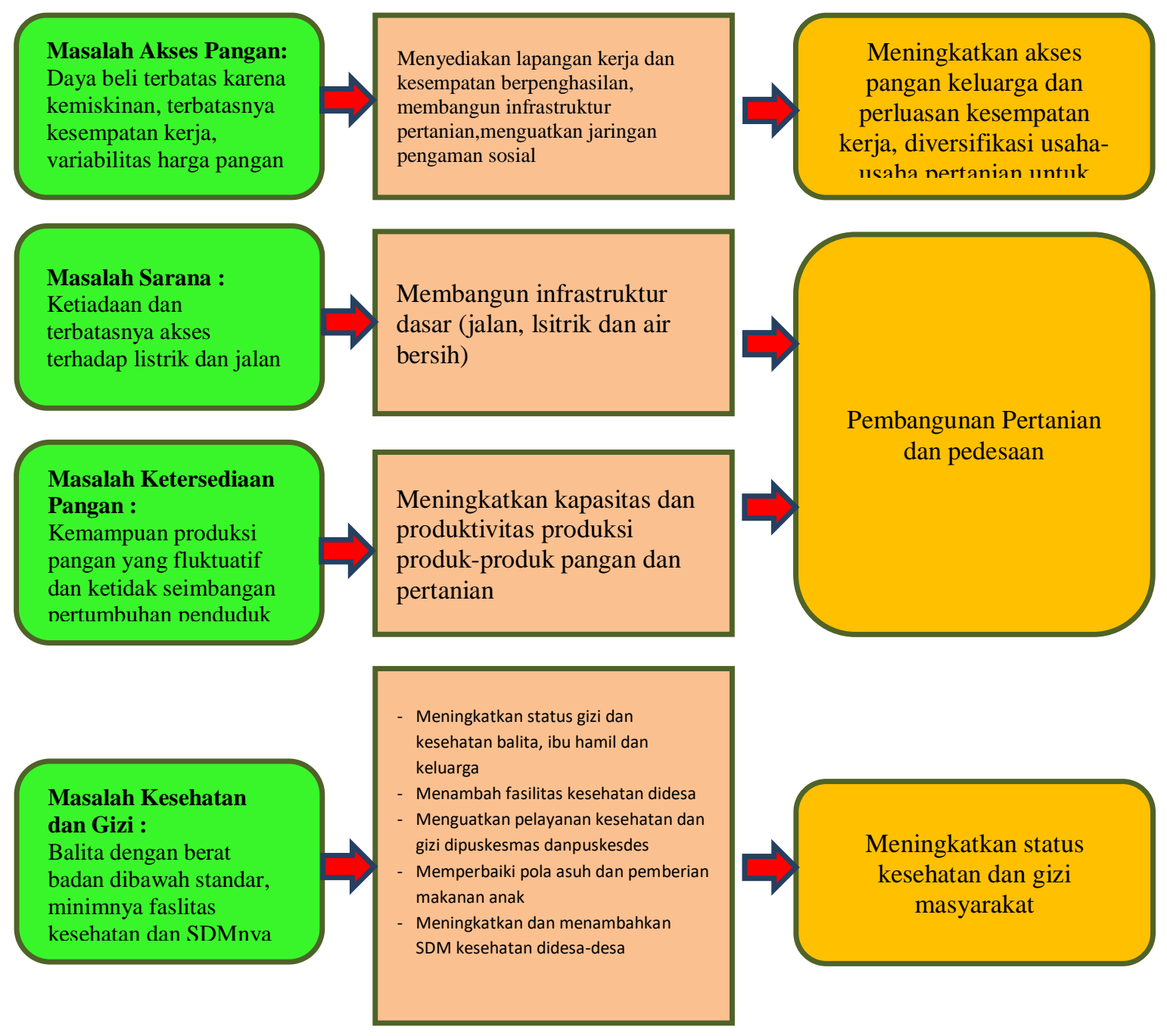

Sumber: Hasil Analisa, 2016

Gambar 1 Kerangka Kerja Penyebab dan Jenis Inteventsi Meningkatkan Ketahanan Pangan

Karakteristik Masing-masing Prioritas dan

Strategi Penanganannya dapat dilihat pada tabel berikut ini : 
Karakteristik Masing-masing Prioritas serta Strategi Penanganannya

\begin{tabular}{|c|c|c|c|c|}
\hline No & Prioritas & $\begin{array}{l}\text { Faktor } \\
\text { Penentu }\end{array}$ & Strategi Penanganan* & Program Daerah* \\
\hline \multirow{11}{*}{1} & \multirow{11}{*}{ Prioritas 1} & \multirow{2}{*}{$\begin{array}{l}\text { Jumlah } \\
\text { warung/toko } \\
\text { kelontongan }\end{array}$} & \multirow{2}{*}{$\begin{array}{l}\text { Meningkatkan } \\
\text { ketersediaan pangan } \\
\text { masyarakat }\end{array}$} & $\begin{array}{l}\text { Peningkatan produksi dan } \\
\text { produktivitas } \\
\text { pertanian/perkebunan }\end{array}$ \\
\hline & & & & $\begin{array}{l}\text { Menggalakkan kegiatan } \\
\text { rumah pangan lestari }\end{array}$ \\
\hline & & \multirow{3}{*}{$\begin{array}{l}\text { Fasilitas } \\
\text { Kesehatan }\end{array}$} & \multirow{3}{*}{$\begin{array}{l}\text { Meningkatkan pelayanan } \\
\text { kesehatan dasar } \\
\text { masyarakat }\end{array}$} & $\begin{array}{l}\text { Menambah dan rehabilitasi } \\
\text { fasilitas layanan kesehatan } \\
\text { didesa-desa; }\end{array}$ \\
\hline & & & & $\begin{array}{l}\text { Menambah jumlah tenaga } \\
\text { kesehatan didesa yang } \\
\text { kondisi geografis luas dan } \\
\text { tidak terintegrasi; }\end{array}$ \\
\hline & & & & $\begin{array}{l}\text { Melatih SDM masyarakat } \\
\text { desa sebagai fasilitator } \\
\text { kesehatan; }\end{array}$ \\
\hline & & \multirow{3}{*}{ Akses Jalan } & \multirow{3}{*}{$\begin{array}{l}\text { Meningkatkan } \\
\text { pembangunan } \\
\text { infrastruktur dasar }\end{array}$} & $\begin{array}{l}\text { Membuka daerah atau desa- } \\
\text { desa yang masih terisolir } \\
\text { dengan membangun } \\
\text { infrastruktur jalan; }\end{array}$ \\
\hline & & & & $\begin{array}{l}\text { Mengarahkan pemanfaatan } \\
\text { dana desa untuk } \\
\text { membangun jalan } \\
\text { penghubung antar desa }\end{array}$ \\
\hline & & & & $\begin{array}{l}\text { Membangun infrastruktur air } \\
\text { bersih }\end{array}$ \\
\hline & & \multirow{3}{*}{ Kemiskinan } & \multirow{3}{*}{$\begin{array}{l}\text { Meningkatkan pendapatan } \\
\text { dan mengupayakan } \\
\text { pemenuhan pelayanan } \\
\text { kebutuhan dasar } \\
\text { masyakarat miskin }\end{array}$} & $\begin{array}{l}\text { Menggalakkan program } \\
\text { diversifikasi usaha dengan } \\
\text { kegiatan produktif rumah } \\
\text { tangga }\end{array}$ \\
\hline & & & & $\begin{array}{l}\text { Memberikan jaminan sosial } \\
\text { bagi masyarakat miskin }\end{array}$ \\
\hline & & & & $\begin{array}{l}\text { Identifikasi potensi unggulan } \\
\text { desa untuk mengembangkan } \\
\text { ekonomi masyarakat }\end{array}$ \\
\hline \multirow[t]{2}{*}{2} & \multirow[t]{2}{*}{ Prioritas 2} & \multirow[t]{2}{*}{ Akses Jalan } & \multirow{2}{*}{$\begin{array}{l}\text { Meningkatkan } \\
\text { pembangunan } \\
\text { infrastruktur dasar }\end{array}$} & $\begin{array}{l}\text { Membuka daerah atau desa- } \\
\text { desa yang masih terisolir } \\
\text { dengan membangun } \\
\text { infrastruktur jalan; }\end{array}$ \\
\hline & & & & $\begin{array}{l}\text { Mengarahkan pemanfaatan } \\
\text { dana desa untuk }\end{array}$ \\
\hline
\end{tabular}




\begin{tabular}{|c|c|c|c|c|}
\hline & & & & $\begin{array}{l}\text { membangun jalan } \\
\text { penghubung antar desa }\end{array}$ \\
\hline & & & & $\begin{array}{l}\text { Membangun infrastruktur air } \\
\text { bersih }\end{array}$ \\
\hline & & & Meningkatkan pendapatan & $\begin{array}{l}\text { Menggalakkan program } \\
\text { diversifikasi usaha dengan } \\
\text { kegiatan produktif rumah } \\
\text { tangga }\end{array}$ \\
\hline & & Kemiskinan & $\begin{array}{l}\text { mengupayakanpemenuhan } \\
\text { pelayanan kebutuhan }\end{array}$ & $\begin{array}{l}\text { Memberikan jaminan sosial } \\
\text { bagi masyarakat miskin }\end{array}$ \\
\hline & & & dasar masyakarat miskin & $\begin{array}{l}\text { Identifikasi potensi unggulan } \\
\text { desa untuk mengembangkan } \\
\text { ekonomi masyarakat }\end{array}$ \\
\hline & & Gini Burul & $>$ Meningkatkan pelayanan & $\begin{array}{l}\text { Optimalisasi pelayanan, } \\
\text { pembinaan dan pengawasan } \\
\text { kesehatan pada anak balita } \\
\text { dan ibu hamil/melahirkan }\end{array}$ \\
\hline & & GiZ1 DuruK & $\begin{array}{l}\text { kesenatan dan sosiallsasi } \\
\text { kesehatan masyarakat }\end{array}$ & $\begin{array}{l}\text { Membina masyarakat desa } \\
\text { sebagai ujung tombak } \\
\text { pelaksanaan pencegahan } \\
\text { terjadinya gizi buruk. }\end{array}$ \\
\hline & & $\begin{array}{l}\text { Jumlah } \\
\text { Warung/ }\end{array}$ & $\begin{array}{l}\text { Meningkatkan } \\
\text { ketersediaan pangan }\end{array}$ & $\begin{array}{l}\text { Peningkatan produksi dan } \\
\text { produktivitas } \\
\text { pertanian/perkebunan }\end{array}$ \\
\hline & & Toko & masyarakat & $\begin{array}{l}\text { Menggalakkan kegiatan } \\
\text { rumah pangan lestari }\end{array}$ \\
\hline 3 & Prioritas 3 & & & $\begin{array}{l}\text { Menambah dan rehabilitasi } \\
\text { fasilitas layanan kesehatan } \\
\text { didesa-desa; }\end{array}$ \\
\hline & & $\begin{array}{l}\text { Fasilitas } \\
\text { Kesehatan }\end{array}$ & $\begin{array}{l}\text { Meningkatkan pelayanan } \\
\text { kesehatan dasar } \\
\text { masyarakat }\end{array}$ & $\begin{array}{l}\text { Menambah jumlah tenaga } \\
\text { kesehatan didesa yang } \\
\text { kondisi geografis luas dan } \\
\text { tidak terintegrasi; }\end{array}$ \\
\hline & & & & $\begin{array}{l}\text { Melatih SDM masyarakat } \\
\text { desa sebagai fasilitator } \\
\text { kesehatan; }\end{array}$ \\
\hline
\end{tabular}

Sumber: Hasil Analisis, 2016

\section{Saran}

Pendekatan jangka pendek dengan mengupayakan membangun peningkatan perekonomian masyarakat pedesaan yang berbasis pertanian pada upaya peningkatan nilai tambah dan peluang penyediaan lapangan kerja. Pendekatan jangka menengah dan panjang adalah dengan memenuhi kecukupan pangan dan gizi golongan masyarakat miskin dan rawan pangan dengan pendekatan pemberdayaan melibatkan partisipasi dan peran akitf seluruh komponen. 


\section{Daftar Pustaka}

Apriyantono, Anton. 2006. Kebijakan Strategis Pembangunan Ketahanan Pangan Nasional. Naskah Pidato pada DiesNatalis ke XX dan Wisuda Sarjana Univertas Islam Darul Ulum. Lamongan Jawa Timur. 9 Desember 2006.

Apriyantono, Anton. 2007. Arahan Umum. Naskah Pidato pada Rapat Koordinasi Percepatan Pembangunan Pertanian Wilayah Kalimantan, Banjarmasin, 27-28 Februari 2007.

Arifin, Bustanul. 2007. "Strategi dan Kebijakan Sektor Pertanian dalam Mewujudkan Kesejahteraan Petani dan Kedaulatan Pangan". Paper disampaikan pada Seminar Milad ke-9 Partai Keadilan Sejahtera: Membela Ekonomi Rakyat-Ketahanan dan Kemandirian Pangan serta Perumahan yang Layak bagi Rakyat, untuk keberlanjutan Pembangunan Bangsa. Jakarta. 20 April 2007.

Arifin, Bustanul. 2004. Analisis Ekonomi Pertanian Indonesia. Jakarta: Penerbit Buku Kompas. Badan Ketahanan Pangan Propinsi JawaTimur. 2005. Pengembangan Desa Mandiri Pangan.Badan Ketahanan Pangan. 2005. Kebijakan Umum Ketahanan Pangan.

Daerobi, Akhmad, Heri Sulistyo Jati, Tetuko Rawidyo Putro. 2006. "Impact of Agricultural Sector on Poverty Alleviation: Conceptual Framework with Empirical Evidence Pre-Post Crisis (Case Study:Central Java)". Makalah dipresentasikanpada Indonesian Regional Science Association (IRSA) International Seminar, 18-19 Agustus 2006, Malang, Jawa Timur.

Departemen Pertanian-Badan Bimas Ketahanan Pangan-Dewan Ketahanan Pangan. 2002. Kajian Situasi Lumbung Pangan Masyarakat di Propinsi Jabardan Jateng. Pusat Pengembangan Ketersediaan Pangan.

Jayawinata, Ardi. 2003. Pemberdayaan Lumbung Pangan Masyarakat. Gizi.net.

Krisnamurthi, Bayu. 2006. Mencari Bentuk Politik Ekonomi Pertanian Indonesia.

Yunastiti Purwaningsih, 2008, Ketahanan Pangan: Situasi, Permasalahan Jurnal Ekonomi Pembangunan, Vol. 9, No. 1, Juni 2008 